\title{
Author Correction: Genome-wide association study of depression phenotypes in UK Biobank identifies variants in excitatory synaptic pathways
}

David M. Howard(D), Mark J. Adams (1D, Masoud Shirali (1), Toni-Kim Clarke, Riccardo E. Marioni, Gail Davies, Jonathan R. I. Coleman (1), Clara Alloza, Xueyi Shen (1), Miruna C. Barbu, Eleanor M. Wigmore, Jude Gibson \& 23andMe Research Team*, Saskia P. Hagenaars, Cathryn M. Lewis (D), Joey Ward, Daniel J. Smith (1), Patrick F. Sullivan, Chris S. Haley (10), Gerome Breen, lan J. Deary \& Andrew M. Mclntosh (1)

Correction to: Nature Communications https://doi.org/10.1038/s41467-018-03819-3, published online 16 April 2018.

The original version of this Article contained an error in the 'Methods' subsection entitled 'Broad depression phenotype', which incorrectly read "Have you ever seen a psychiatrist for nerves, anxiety, tension or depression”? (UK Biobank field 2010)'. The same error was made three times in the subsections 'Probable MDD phenotype' and 'ICD-coded MDD phenotype', which read '(UK Biobank fields: 2090 and 2010)'. The correct version states '2100' in place of '2010' in each case. This has been corrected in both the PDF and HTML versions of the Article.

Published online: 25 March 2021

(i) Open Access This article is licensed under a Creative Commons Attribution 4.0 International License, which permits use, sharing, adaptation, distribution and reproduction in any medium or format, as long as you give appropriate credit to the original author(s) and the source, provide a link to the Creative Commons license, and indicate if changes were made. The images or other third party material in this article are included in the article's Creative Commons license, unless indicated otherwise in a credit line to the material. If material is not included in the article's Creative Commons license and your intended use is not permitted by statutory regulation or exceeds the permitted use, you will need to obtain permission directly from the copyright holder. To view a copy of this license, visit http://creativecommons.org/licenses/by/4.0/.

(C) The Author(s) 2021 